\title{
Obesity and Pro12Ala Polymorphism of Peroxisome Proliferator-Activated Receptor-Gamma Gene in Healthy Adults: A Systematic Review and Meta-Analysis
}

\author{
Anahita Mansoori ${ }^{a}$ Maryam Amini ${ }^{b}$ Fariba Kolahdooz ${ }^{c}$ \\ Ensiyeh Seyedrezazadeh ${ }^{c}$ \\ ${ }^{a}$ Cellular and Molecular Nutrition Department, School of Nutritional Sciences and Dietetics, Tehran University \\ of Medical Sciences and ${ }^{\mathrm{b}}$ Department of Nutrition Research, National Nutrition and Food Technology Research \\ Institute, Faculty of Nutrition Sciences and Food Technology, Shahid Beheshti University of Medical Sciences, \\ Tehran and 'Tuberculosis and Lung Research Center, Tabriz University of Medical Sciences, Tabriz, Iran
}

\section{Key Words}

Obesity · Peroxisome proliferator-activated receptor-gamma Pro12Ala polymorphism . Body mass index

\begin{abstract}
Background: The aim of this systematic review was to evaluate the relationship between obesity and peroxisome proliferator-activated receptor-gamma (PPARY) Pro12Ala polymorphism in healthy adults. Summary: Weighted mean differences (WMDs) of body mass index (BMI) were calculated for different inheritance models and subgroups. Fifty-six studies were eligible for inclusion in the meta-analysis. The result shows that the Ala allele of this polymorphism was associated with increased WMD in mean BMI (WMD $=0.29$, $95 \% \mathrm{Cl} 0.10-0.48, \mathrm{p}=0.003)$. The Ala carriers were associated with increased WMD in mean BMI values in both genders and in the Caucasian subgroup. The associations were seen among people with higher levels of $\mathrm{BMI}$ (BMI $\geq 35$ ). Message: The Ala allele of the PPARy Pro12Ala polymorphism in healthy adults was associated with increased BMI under a dominant model of inheritance.

(c) 2015 S. Karger AG, Basel
\end{abstract}

\section{Introduction}

Pathogenesis of obesity is multifactorial and involves both genetics and environmental factors [1]. Many genes are involved in regulatory pathways for weight gain and obesity. These genes include leptin, leptin receptors, melanocortin receptor 4, mitochondrial uncoupling proteins, peroxisome proliferator-activated receptor-gamma (PPAR $\gamma)$, neuropeptide $\mathrm{Y}$, and ghrelin as well as genes in signaling pathways [2]. PPARs are ligand-dependent transcription factors that are involved in the genetic regulation of mammalian metabolism [3]. PPAR $\gamma$ plays a pivotal role in the regulation of adipocyte differentiation, energy storage, insulin sensitivity, and lipid metabolism [3]. A point mutation found on the $\mathrm{B}$ exon of the $\mathrm{NH} 2$-terminal of PPAR $\gamma$, substitution of proline with alanine at position 12 (PPAR $\gamma$ Pro12Ala SNP) (rs1801282), causes a moderate decrease in its transcription activity and adipogenic potential $[4,5]$. Several meta-analyses and genomewide association studies have confirmed the relationship between the Pro variant and the risk of type 2 diabetes [6]. Recently, new opportunities for human genome research have appeared; many studies have been conducted in this

\section{KARGER 125}

(c) 2015 S. Karger AG, Base

$0250-6807 / 15 / 0672-0104 \$ 39.50 / 0$

E-Mail karger@karger.com

www.karger.com/anm
Ensiyeh Seyedrezazadeh

Tuberculosis and Lung Research Center, Emam Reza Medical Research and Training Hospital, Tabriz University of Medical Sciences

University Street, PO Box 5166614756, Tabriz (Iran)

E-Mail e.s.rezazadeh@gmail.com 
area, but evidence for obesity is limited and inconsistent $[7,8]$. Some studies have shown an association between the aforementioned single nucleotide polymorphism (SNP) and obesity $[9,10]$, but these have not been confirmed by other studies $[11,12]$. Some systematic studies were conducted in regard to the association of this particular SNP and obesity [13-15]. However, the participants in most of the studies included were diabetic patients. Considering the fact that a significantly higher rate of overweight and obesity was found in persons with type 2 diabetes as compared to the general population, and that nutritional intervention and oral hypoglycemic agents in diabetic patients might affect their body weight [16], this study also suggested a potential interaction between this SNP and dietary intervention on body weight $[17,18]$; thus, it may limit the generalizability of previous findings to healthy individuals. Therefore, the present systematic review and meta-analyses aim to investigate the association between obesity and Pro12Ala polymorphism of PPAR $\gamma$ gene in healthy adults.

\section{Methods}

\section{Search Strategy}

This study was conducted with a prospective protocol, which included a predefined research question, search strategy, study eligibility criteria, and methods of data extraction and statistical analysis. We followed preferred reporting items for systematic reviews and meta-analyses guidelines for the reporting of this study [19].

We performed a systematic search for relevant studies by the 3 major databases PubMed, Embase, and Scopus in English up to April 2014, which involved humans. The key terms and medical subject heading $[\mathrm{MeSH}]$ were used in different combinations of the following search criteria: 'obesity' $[\mathrm{MeSH}]$, 'obese', 'overweight', 'body weight', 'body fat', 'body mass index', 'BMI', 'skinfold thickness', 'adiposity', 'body composition', 'peroxisome proliferator-activated receptor gamma', 'PPARgamma' [MeSH], 'peroxisomeproliferator-activated receptor-gamma2', 'PPARgamma2', 'PPARG', 'PPARG2', 'peroxisome proliferators-activated receptor', 'PPAR', 'PPAR 2', 'Pro12Ala', 'P12A', 'Ala12', 'Pro12', 'Ala carrier', and 'non-Ala carrier'. Furthermore, we reviewed reference lists of the obtained articles to search for additional studies.

\section{Selection Criteria}

The predetermined inclusion criteria of the original studies were (1) studies that included the mean BMI values for each genotype of the Pro12Ala polymorphism of PPAR $\gamma$ gene (2) cohort studies, clinical trials, population case-control studies (investigating healthy participants with no matching between control and cases) or crosssectional studies. If the data were duplicated in more than 1 study, the most recent and comprehensive study was included in the metaanalysis. Exclusion criteria included (1) studies that do not meet the inclusion criteria, (2) participants less than 18 years of age, (3) unhealthy subjects with cancer, diabetes, cardiovascular disease, polycystic ovary syndrome and other endocrine dysfunctions.

PPAR $\gamma$ Pro12Ala Polymorphism in

Relation to Obesity

\section{Data Extraction}

All relevant articles were reviewed and duplicates deleted. Relevant articles (titles and abstracts) were screened by the authors (A.M. and M.A.) independently to select potentially articles for the review. The studies reporting our data of interest were screened for eligibility. For each included study, the following information was extracted: first author name, year of publication, mean and SD or SE of BMI by genotypes, country of study, racial background of the subjects, study design, source of the study population, gender, age, sample size, and confounding factors accounted for.

\section{Statistical Analysis}

The mean difference and SD of BMI in cohort, population casecontrol, cross-sectional studies, and the first data of clinical trials were considered. When SE or CI were reported, the values of SD were calculated. The frequencies of Ala/Ala homozygote in individuals are extremely rare. To ensure adequate statistical power, we included individuals with the Pro/Ala genotype along with individuals with the Ala/Ala genotype (as $\mathrm{Ala}^{+}$) when comparing their data with individuals with the Pro/Pro (as $\mathrm{Ala}^{-}$). Moreover, both dominant and recessive models were performed for studies that mentioned BMI values for Ala/Ala genotype.

Between-study heterogeneity was evaluated by Cochran's Q statistical test and $\mathrm{I}^{2}$ metric [20], which describe the percentage of total variation in point estimates attributable to genuine variation rather than sampling error, and notable considered when $\mathrm{I}^{2}$ was $>50 \%$ [21]. A threshold of $\mathrm{p}<0.1$ was used to identify the presence of heterogeneity. Random-effects models were used to calculate the pooled mean difference of BMI level in response to genotype [22]. The weighted mean difference (WMD) was used as a measure of the relationship between Pro12Ala polymorphism of PPAR $\gamma$ gene and BMI. Potential sources of heterogeneity were identified in predefined subgroups including gender (male, female), ethnicity (Caucasian, Asian, and mixed populations, for example, African and Latin American), study design, and following the hypothesis that Ala carrier of this particular SNP may have a stronger effect on $\mathrm{BMI}$ in markedly obese persons, and in order to compare the results of the current study with those of the previous study [13], we also stratified by BMI levels $\left(<27,27 \leq,<35\right.$, and $\left.\geq 35 \mathrm{~kg} / \mathrm{m}^{2}\right)$.

A cumulative meta-analysis was performed to show the consequence of adding studies on the effect size over time [23]. Publication bias was assessed by funnel plot and formal testing for asymmetric of funnel plot using Egger's test [24]. The funnel plot was considered to be asymmetrical if the intercept of Egger's regression deviation deviated from zero with $\mathrm{p}<0.1$. The meta-analysis was conducted using Stata software (version 12.0; StataCorp, College Station, Tex., USA). All the $\mathrm{p}$ values were 2 -sided and the results were regarded as statistically significant if $\mathrm{p}<0.05$.

\section{Results}

\section{Description of Studies}

A total of 363 potentially relevant citations were retrieved by searching databases. Twelve articles were excluded because of duplication. Another 213 studies were excluded during the review because they were in vitro or review studies, studies which genotyped other PPAR $\gamma$ 
Fig. 1. Studies selection process.

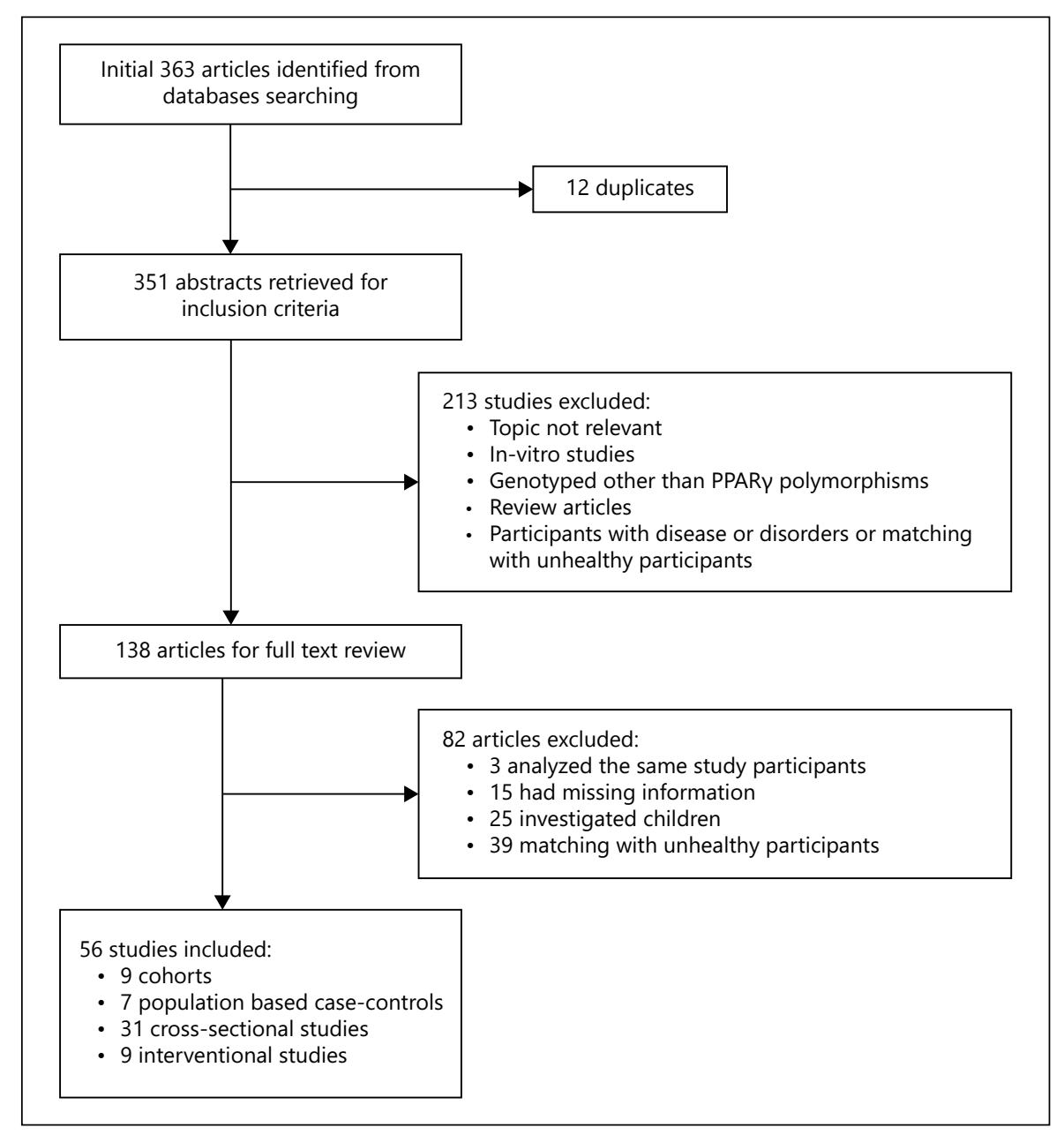

polymorphisms, and studies with other disease or disorders population. Therefore, full text of 138 eligible articles was evaluated. After careful review of the content, another 82 studies were excluded because of missing information, reporting on the same study participants, investigating children, and including participants with a variety of disease or disorders. Finally, a total of 56 articles fulfilled the eligibility criteria and were included in the meta-analyses. The flow diagram of the selection process for the meta-analysis is displayed in figure 1.

Nine cohort studies [12, 25-32], 7 population casecontrol studies [33-39], 31 cross-sectional studies [5, 7, $10,40-67]$, and 9 interventional studies [8, 68-75] were included in the meta-analysis of the association between PPAR $\gamma$ Pro12Ala polymorphism and obesity. The characteristics and results of the studies are summarized in table 1. Seven population case-control studies [33-39], and 1 cross-sectional study [10] provided their data in 2 datasets. Each dataset was treated as a separate comparison in the meta-analysis. Forty studies were on Caucasians $[5,8$, $10,12,25-29,32-39,41-43,45-48,52-54,57,60-70], 10$ studies were on Asian [31, 40, 49, 50, 55, 56, 58, 59, 71, 72] and 6 studies were on mixed populations $[7,30,37,73-$ 75]. Between 56 studies, 19 studies provided data on male $[10,12,29,33,35,37,40,42,43,47,50,57,60-62,65,66$, $69,71]$ and 22 studies on female members $[10,12,29,32$, $37,41,42,50,53-55,59-62,64,66,68,69,72-74]$.

\section{Pooled Analyses \\ Overall Studies}

A total of 39,647 participants were included in this meta-analysis. Of these participants, 31,988 of them had Pro/Pro genotype $(80.68 \%)$ and 7,623 were carriers of the Ala allele (19.22\%). We performed meta-analyses on total comparisons. The pooled analysis of whole studies on the association between WMD of BMI and PPAR $\gamma$ Pro12Ala polymorphism showed mild association of Ala carriers $\left(\mathrm{Ala}^{+}\right)$with increased WMD of BMI than 
Table 1. General information of included studies

\begin{tabular}{|c|c|c|c|c|c|c|c|c|c|}
\hline $\begin{array}{l}\text { Author } \\
\text { (reference) }\end{array}$ & Year & Country & Ethnicity & $\begin{array}{l}\text { Sample } \\
\text { size }\end{array}$ & $\mathrm{M} / \mathrm{F}$ & \multicolumn{2}{|l|}{$\mathrm{Ala}^{-}$} & \multicolumn{2}{|l|}{$\mathrm{Ala}^{+}$} \\
\hline Schäffler et al. [26] & 2001 & Germany & Caucasian & 359 & $149 / 210$ & 276 & $27.2 \pm 6.4$ & 83 & $27.47 \pm 6.31$ \\
\hline Robitaille et al. [27] & 2003 & Canada & Caucasian & 720 & $313 / 407$ & 582 & $26.9 \pm 7.2$ & 132 & $28.2 \pm 7$ \\
\hline Pihlajamäki et al. [28] & 2004 & Finland & Caucasian & 311 & $145 / 166$ & 208 & $25.7 \pm 4.4$ & 103 & $26.02 \pm 4.18$ \\
\hline Franks et al. [29] ${ }^{\dagger}$ & 2004 & $\begin{array}{l}\text { United } \\
\text { Kingdom }\end{array}$ & Caucasian & 506 & $226 / 280$ & 399 & $26.56 \pm 8.47$ & 107 & $26.66 \pm 7.75$ \\
\hline Aldhoon et al. [32] & 2010 & Czech & Caucasian & 237 & F: 237 & 218 & $35.9 \pm 3.95$ & 19 & $40.25 \pm 5.8$ \\
\hline $\begin{array}{l}\text { Population case-control } \\
\text { Ek et al. }[33]^{\dagger}\end{array}$ & $\begin{array}{l}\text { studies } \\
1999\end{array}$ & Denmark & Caucasian & $\begin{array}{l}\text { Case: } 752 \\
\text { Control: } 869\end{array}$ & $\begin{array}{l}\text { M: } 752 \\
\text { M: } 869\end{array}$ & $\begin{array}{l}540 \\
641 \\
\end{array}$ & $\begin{array}{l}35.5 \pm 5.5 \\
26.2 \pm 3.7\end{array}$ & $\begin{array}{l}212 \\
228\end{array}$ & $\begin{array}{r}36.29 \pm 5.85 \\
25.9 \pm 3.17 \\
\end{array}$ \\
\hline Clement et al. [34] & 2000 & France & Caucasian & $\begin{array}{l}\text { Case: } 372 \\
\text { Control: } 295\end{array}$ & $\begin{array}{l}77 / 295 \\
100 / 195\end{array}$ & $\begin{array}{l}294 \\
246\end{array}$ & $\begin{array}{l}47 \pm 7.5 \\
22 \pm 1.9\end{array}$ & $\begin{array}{l}78 \\
49\end{array}$ & $\begin{array}{r}48 \pm 7.5 \\
22.3 \pm 1.9 \\
\end{array}$ \\
\hline Ek et al. [35] & 2001 & Sweden & Caucasian & $\begin{array}{l}\text { Case: } 616 \\
\text { Control: } 364\end{array}$ & $\begin{array}{l}M: 616 \\
184 / 180\end{array}$ & $\begin{array}{l}456 \\
270\end{array}$ & $\begin{array}{l}25.6 \pm 3 \\
23.5 \pm 3.6\end{array}$ & $\begin{array}{r}160 \\
64\end{array}$ & $\begin{array}{c}25.66 \pm 3.24 \\
23.1 \pm 3.2\end{array}$ \\
\hline Swarbrick et al. [36] & 2001 & Australia & Caucasian & $\begin{array}{l}\text { Case: } 292 \\
\text { Control: } 371\end{array}$ & $\begin{array}{l}145 / 147 \\
180 / 191\end{array}$ & $\begin{array}{l}215 \\
277\end{array}$ & $\begin{array}{r}32.9 \pm 2.6 \\
22 \pm 1.8\end{array}$ & $\begin{array}{l}77 \\
94\end{array}$ & $\begin{array}{l}32.9 \pm 2.6 \\
22.1 \pm 2\end{array}$ \\
\hline $\begin{array}{l}\text { Cross-sectional studies } \\
\text { Deeb et al. [5] }]^{\dagger}\end{array}$ & 1998 & Finland & $\begin{array}{l}\text { Caucasian } \\
\text { Caucasian }\end{array}$ & $\begin{array}{l}333 \\
973\end{array}$ & $\begin{array}{l}165 / 168 \\
357 / 616\end{array}$ & $\begin{array}{l}257 \\
695\end{array}$ & $\begin{array}{l}26.2 \pm 3.2 \\
27.3 \pm 5.3\end{array}$ & $\begin{array}{r}76 \\
278\end{array}$ & $\begin{array}{c}25 \pm 3.5 \\
27.74 \pm 4.74\end{array}$ \\
\hline Mori et al. [40] & 1998 & Japan & Asian & 215 & M: 215 & 203 & $24.4 \pm 3.3$ & 12 & $24 \pm 3$ \\
\hline Beamer et al. [10]* & 1998 & USA & $\begin{array}{l}\text { Caucasian } \\
\text { Caucasian }\end{array}$ & $\begin{array}{l}169 \\
517\end{array}$ & $\begin{array}{l}57 / 112 \\
316 / 201\end{array}$ & $\begin{array}{l}141 \\
408\end{array}$ & $\begin{array}{l}35.3 \pm 8.31 \\
26.1 \pm 4.04\end{array}$ & $\begin{array}{r}28 \\
109\end{array}$ & $\begin{array}{l}41.5 \pm 8.46 \\
27.3 \pm 4.18\end{array}$ \\
\hline Valve et al. [41] & 1999 & Finland & Caucasian & 141 & F: 141 & 107 & $34.5 \pm 3.8$ & 34 & $35.58 \pm 3.4$ \\
\hline Meirhaeghe et al. [42] $^{\dagger}$ & 2000 & France & Caucasian & 838 & $421 / 418$ & 661 & $25.5 \pm 4.4$ & 177 & $26.2 \pm 4.5$ \\
\hline Poirier et al. [43] & 2000 & France & Caucasian & 675 & M: 675 & 507 & $23.3 \pm 2.25$ & 168 & $23.45 \pm 3.36$ \\
\hline Vaccaro et al. [17] & 2007 & Italy & Caucasian & 438 & $315 / 123$ & 365 & $25.6 \pm 4.4$ & 73 & $26.6 \pm 4.6$ \\
\hline Eriksson et al. [45] & 2002 & Finland & Caucasian & 476 & $171 / 305$ & 324 & $27.5 \pm 4.4$ & 152 & $28 \pm 4.3$ \\
\hline Stumvoll et al. [67] & 2002 & Germany & Caucasian & 318 & NR & 242 & $25.8 \pm 2.48$ & 76 & $24.4 \pm 4.35$ \\
\hline
\end{tabular}

PPAR $\gamma$ Pro12Ala Polymorphism in Relation to Obesity 
Table 1. (continued)

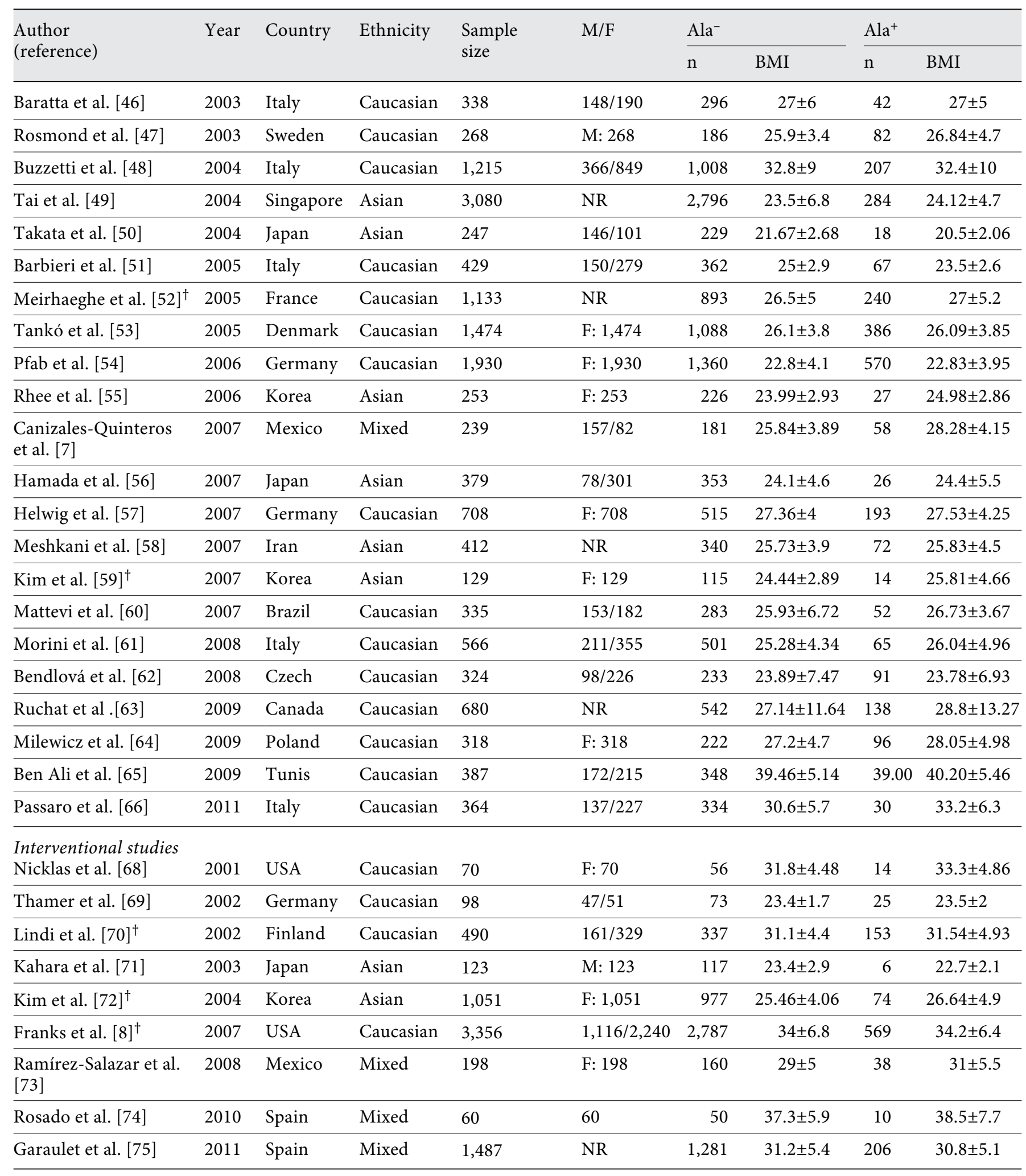

* Two datasets were included; ${ }^{\dagger}$ the same author with different article.

$\mathrm{M}=$ Male; $\mathrm{F}=$ female; $\mathrm{NR}=$ not reported. 
Table 2. Meta-analysis of the association between WMD of BMI and PPAR $\gamma$ Pro12Ala polymorphism

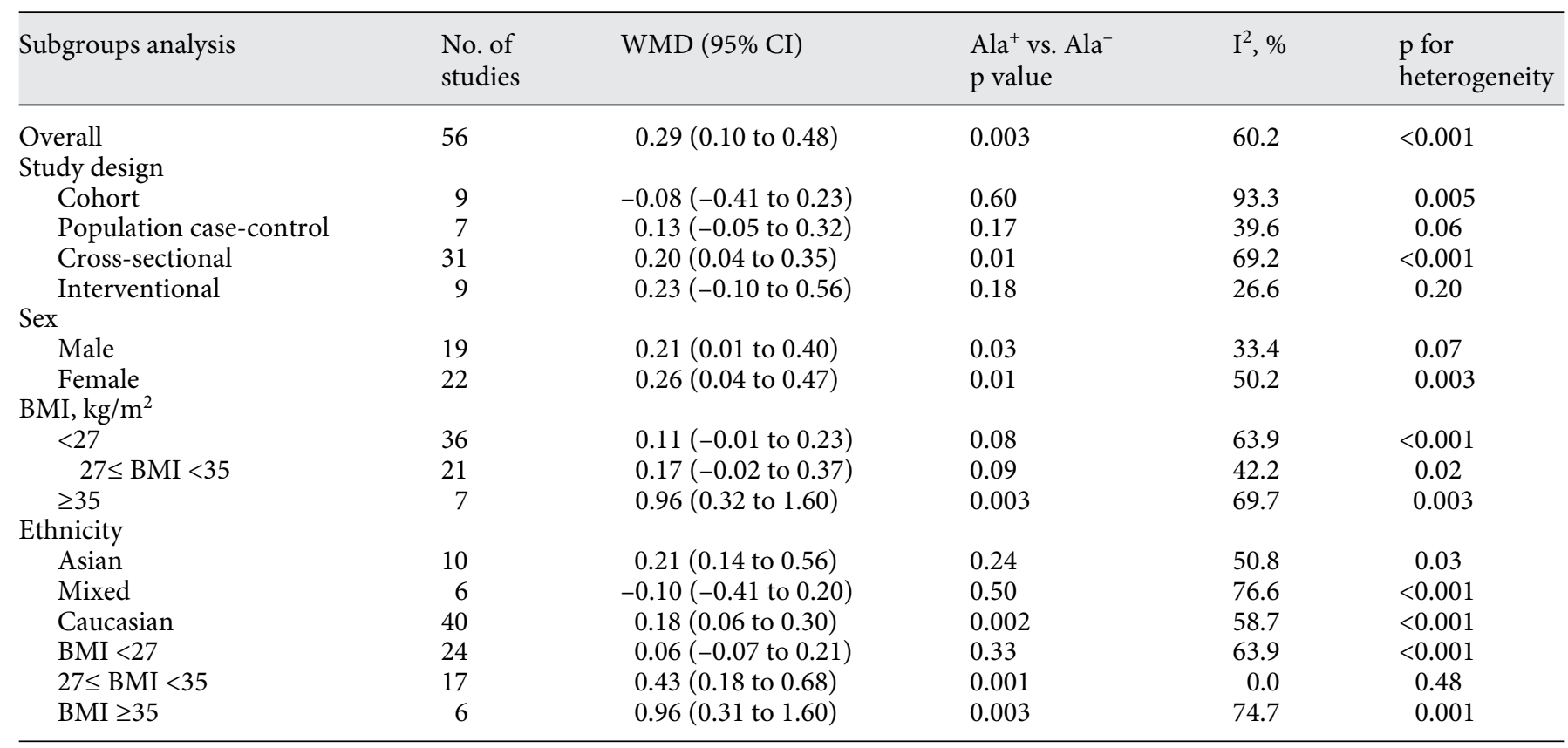

non-Ala carriers $\left(\mathrm{Ala}^{-}\right)(\mathrm{WMD}=0.29,95 \% \mathrm{CI} 0.10-0.48$, $\mathrm{Ala}^{+}$vs. $\mathrm{Ala}^{-} \mathrm{p}=0.003$ ), and with significant heterogeneity ( $\mathrm{p}$ for heterogeneity $<0.001, \mathrm{I}^{2}=60.2 \%$; table 2 ; fig. 2 ). Further analyses were performed for gender, ethnicity, BMI status, and study design subgroups to investigate the source of heterogeneity (table 2). In subgroup analyses for study design, significant heterogeneity was found for cohort and cross-sectional studies ( $\mathrm{p}$ for heterogeneity = 0.005 and $<0.001$, respectively), but not for interventional and population case-control studies (table 2).

\section{Gender}

Following stratification based on gender, the pooled analysis showed the association of $\mathrm{Ala}^{+}$and mild increase of WMD of BMI in both male (WMD $=0.21,95 \%$ CI $0.01-$ $0.40, \mathrm{Ala}^{+}$vs. $\left.\mathrm{Ala}^{-} \mathrm{p}=0.03\right)$ and female $(\mathrm{WMD}=0.26,95 \%$ CI 0.04-0.47, Ala $^{+}$vs. Ala ${ }^{-} \mathrm{p}=0.01$ ) patients (fig. 3). Moreover, each subgroup was heterogeneous for male ( $\mathrm{p}$ for heterogeneity $=0.07, \mathrm{I}^{2}=33.4 \%$ ) and for female ( $\mathrm{p}$ for heterogeneity $=0.003, \mathrm{I}^{2}=50.2 \%$ ) participants.

\section{BMI}

The pooled analysis by BMI status showed a strong association between $\mathrm{Ala}^{+}$and the increment of WMD of BMI for BMI $\geq 35$ (WMD $=0.96,95 \%$ CI $0.32-1.60, \mathrm{Ala}^{+}$ vs. Ala $\left.{ }^{-} \mathrm{p}=0.003\right)$, $\mathrm{p}$ for heterogeneity $=0.003, \mathrm{I}^{2}=69.7 \%$ (table 2; fig. 4).
Ethnicity

Stratified analyses by ethnicity (Caucasian, Asian, and mixed populations) showed that the $\mathrm{Ala}^{+}$was associated with increased WMD in mean BMI values in the Caucasian subgroup in comparison with $\mathrm{Ala}^{-}(\mathrm{WMD}=0.18$, 95\% CI 0.06-0.30, $\mathrm{Ala}^{+}$vs. $\mathrm{Ala}^{-} \mathrm{p}=0.002$; fig. 5). All ethnicity subgroups were heterogeneous (heterogeneity test for Caucasian $\mathrm{p}<0.001, \mathrm{I}^{2}=58.7 \%$, for Asian $\mathrm{p}=0.03$, $\mathrm{I}^{2}=50.8 \%$ and for mixed populations $\mathrm{p}<0.001, \mathrm{I}^{2}=$ $76.6 \%)$. More investigation by BMI categories in Caucasians showed that in both $27 \leq \mathrm{BMI}<35$ and $\mathrm{BMI} \geq 35$ subgroups, $\mathrm{Ala}^{+}$was associated with an increased WMD of BMI (table 2).

\section{Pooled Analyses of Studies in Dominant and Recessive Models}

Fourteen studies presented BMI values for Ala/Ala genotype. In the 14 studies under a dominant model (Pro/Pro in compared with Pro/Ala and Ala/Ala combinations), the mean BMI was higher in Ala carriers than in non-Ala carriers (WMD $=0.22,95 \%$ CI $0.04-$ $0.41, \mathrm{Pro} / \mathrm{Ala}+\mathrm{Ala} / \mathrm{Ala}$ vs. Pro/Pro $\mathrm{p}=0.01)$. However, under a recessive model (Pro/Pro and Pro/Ala combined in compared with Ala/Ala), there was no significant difference between genotypes (WMD $=0.91,95 \%$ $\mathrm{CI}-0.11$ to 1.93 , Ala/Ala vs. Pro/Pro + Pro/Ala $\mathrm{p}=0.08$; fig. 6). 


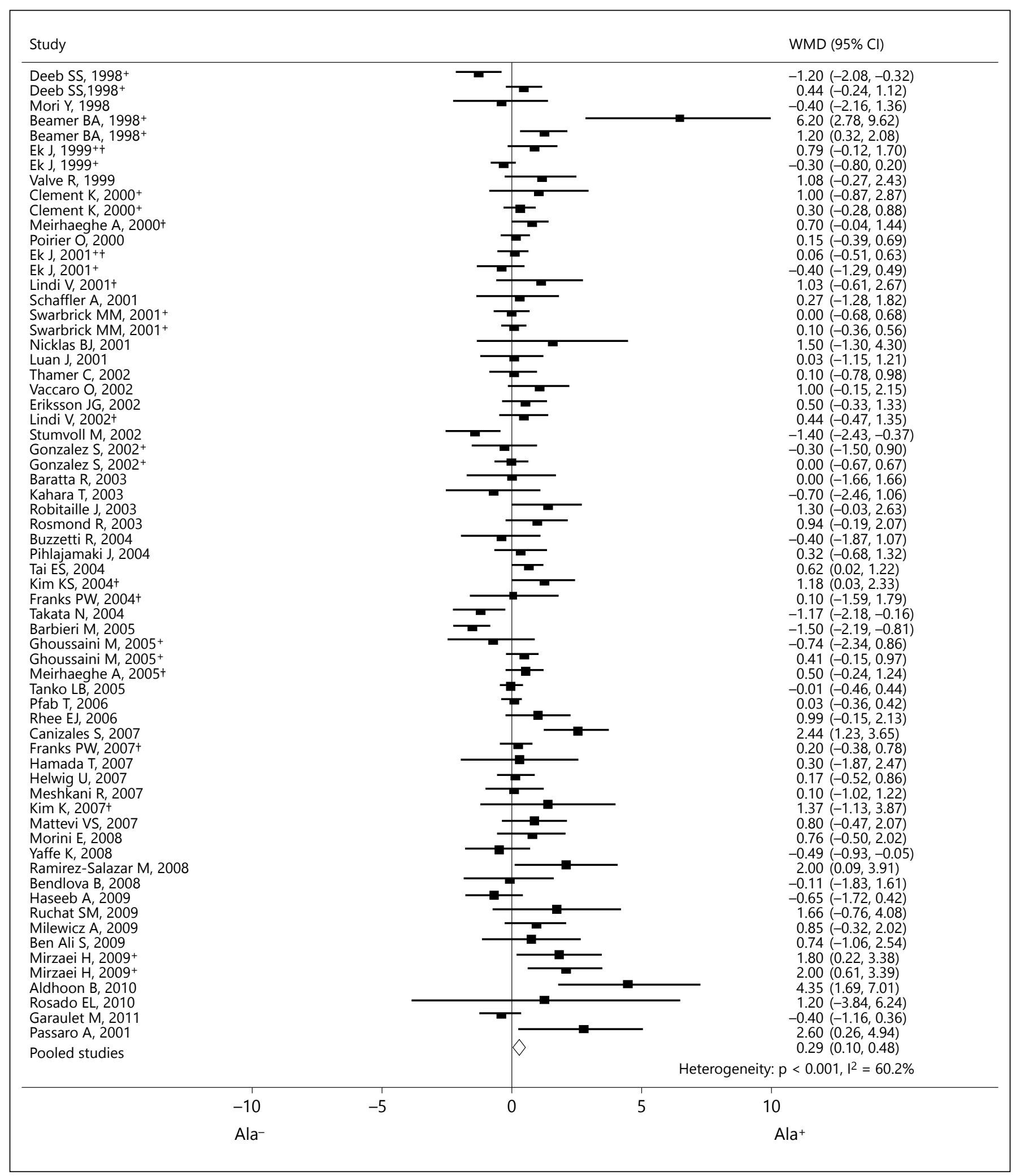

Fig. 2. Association between PPAR $\gamma$ polymorphisms and WMD of BMI. Forest plot showing individual and pooled WMD (95\% CI) for the association between the PPAR $\gamma$ Pro12Ala polymorphisms and BMI. * Two datasets were included; ${ }^{\dagger}$ the same author with different article. 


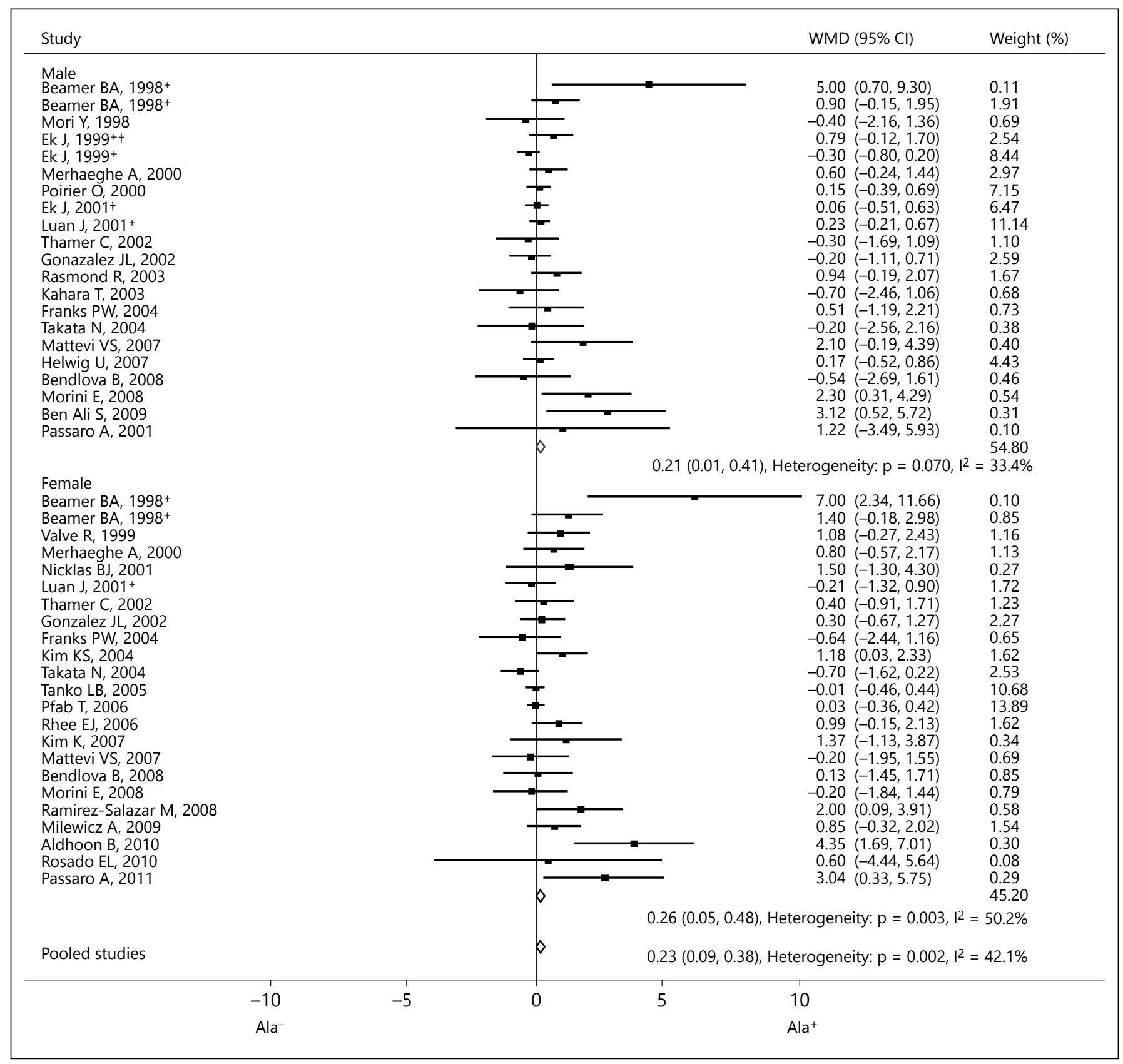

Fig. 3. Association between PPAR $\gamma$ polymorphisms and WMD of $\mathrm{BMI}$, in sex subgroups. Forest plot showing individual and pooled WMD (95\% CI) for the association between the PPAR $\gamma$ Pro12Ala polymorphisms and mean BMI by gender. Diamonds show the
WMD estimated for each subgroup. Test of overall effect: $z=2.09$, $\mathrm{p}=0.03$ for male and $\mathrm{z}=2.38, \mathrm{p}=0.01$ for female. ${ }^{+}$Two datasets were included; ${ }^{\dagger}$ the same author with a different article.

Fig. 4. Association between PPAR $\gamma$ polymorphisms and WMD of BMI. Forest plot showing individual and pooled WMD (95\% CI) for the association between the PPAR $\gamma$ Pro12Ala and BMI.

Fig. 5. Association between PPAR $\gamma$ polymorphisms and WMD of BMI by ethnicity. Forest plot showing individual and pooled WMD (95\% CI) for the association between the PPAR $\gamma$ Pro12Ala polymorphisms and BMI by ethnicity (Caucasian, Asian and mixed population). Diamonds show the WMD estimated for each subgroup. Test of overall effect: $\mathrm{z}=3.03, \mathrm{p}=0.002$ for Caucasian and $\mathrm{z}=1.16, \mathrm{p}=0.24$ for Asian. $\mathrm{z}=0.67, \mathrm{p}=0.50$ for mixed population. ${ }^{+}$Two datasets were included; ${ }^{\dagger}$ the same author with different article.

(For figures 4 and 5 see next pages.)
PPAR $\gamma$ Pro12Ala Polymorphism in Relation to Obesity 


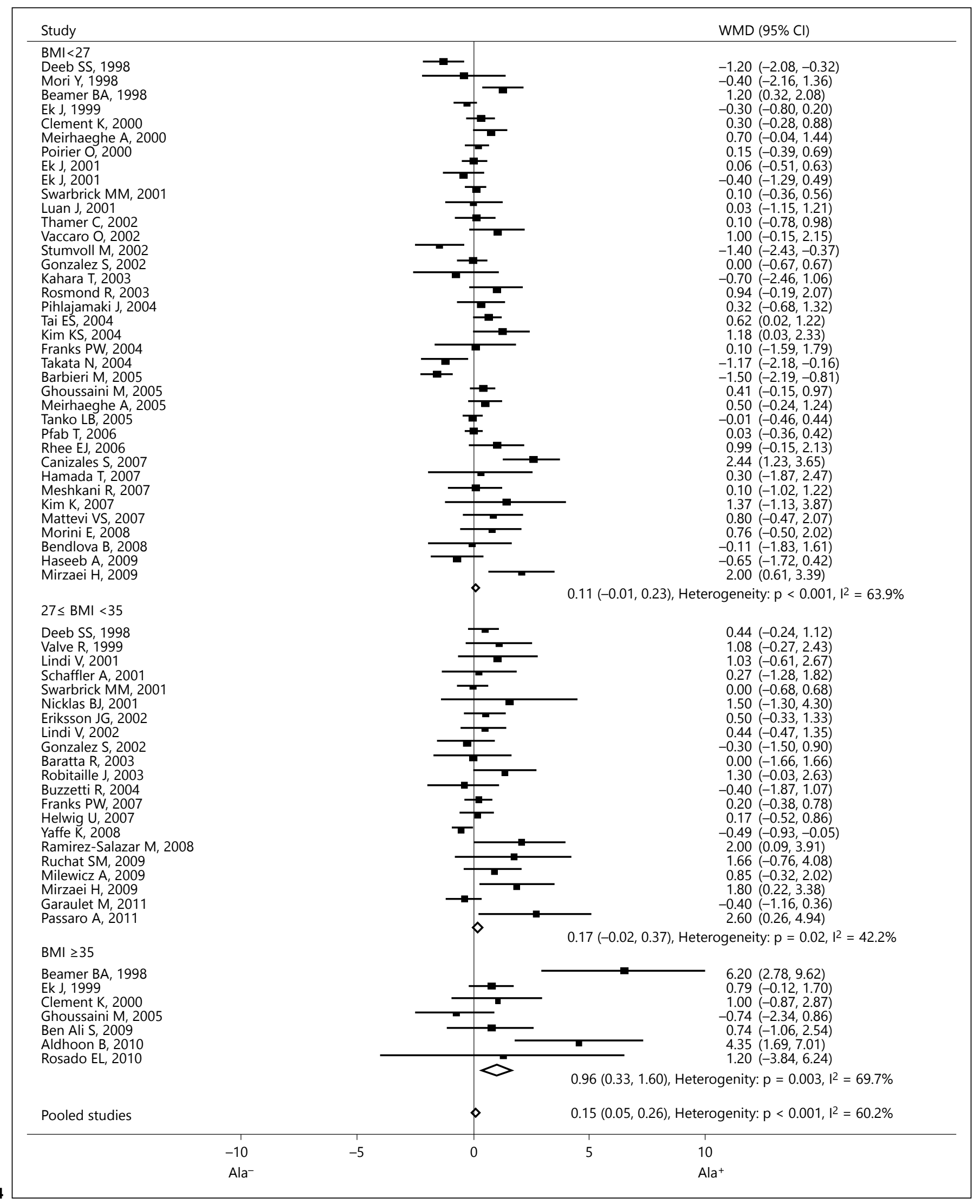

Mansoori/Amini/Kolahdooz/ Seyedrezazadeh 


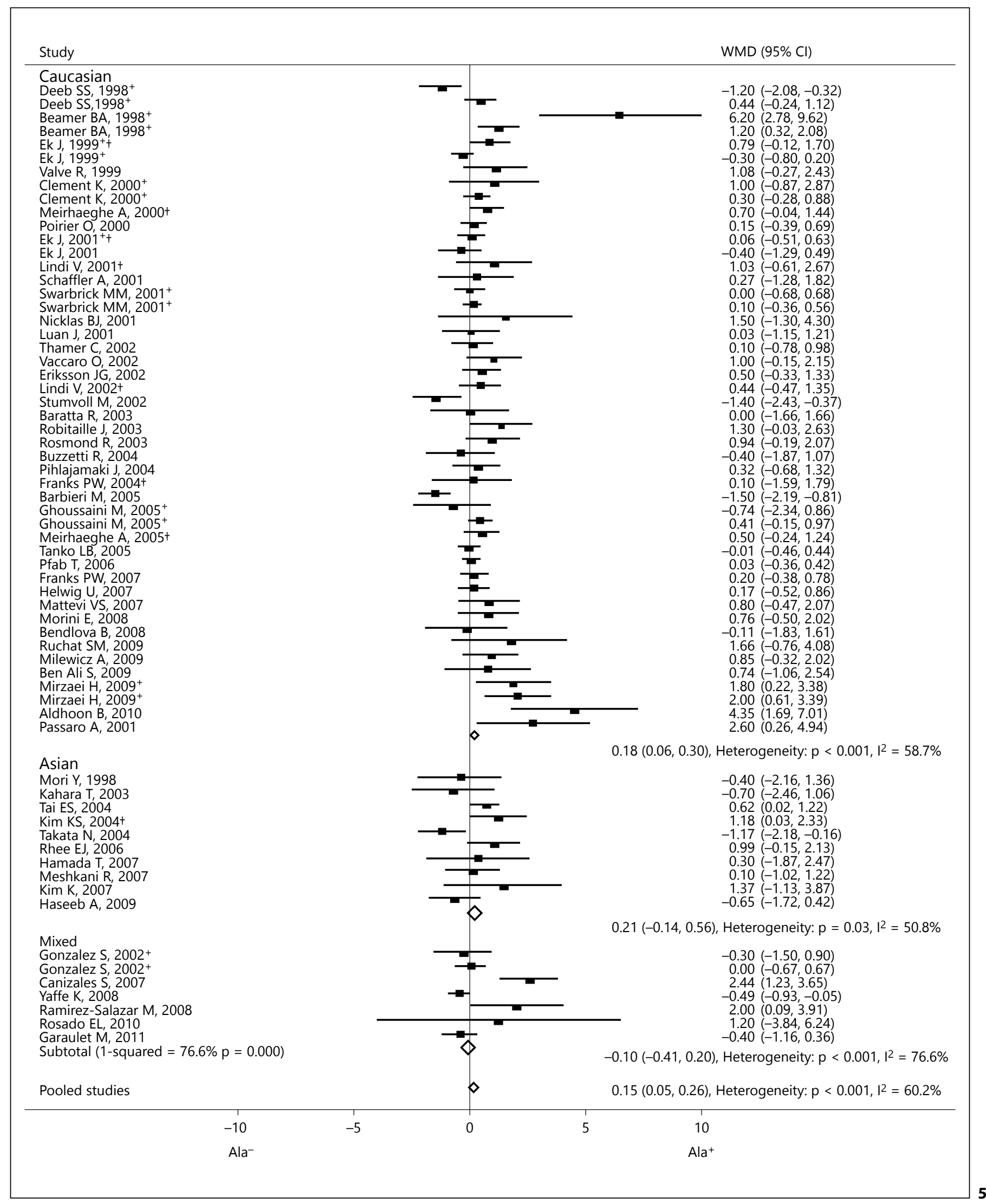

PPAR $\gamma$ Pro12Ala Polymorphism in Relation to Obesity
Ann Nutr Metab 2015;67:104-118 DOI: $10.1159 / 000439285$ 


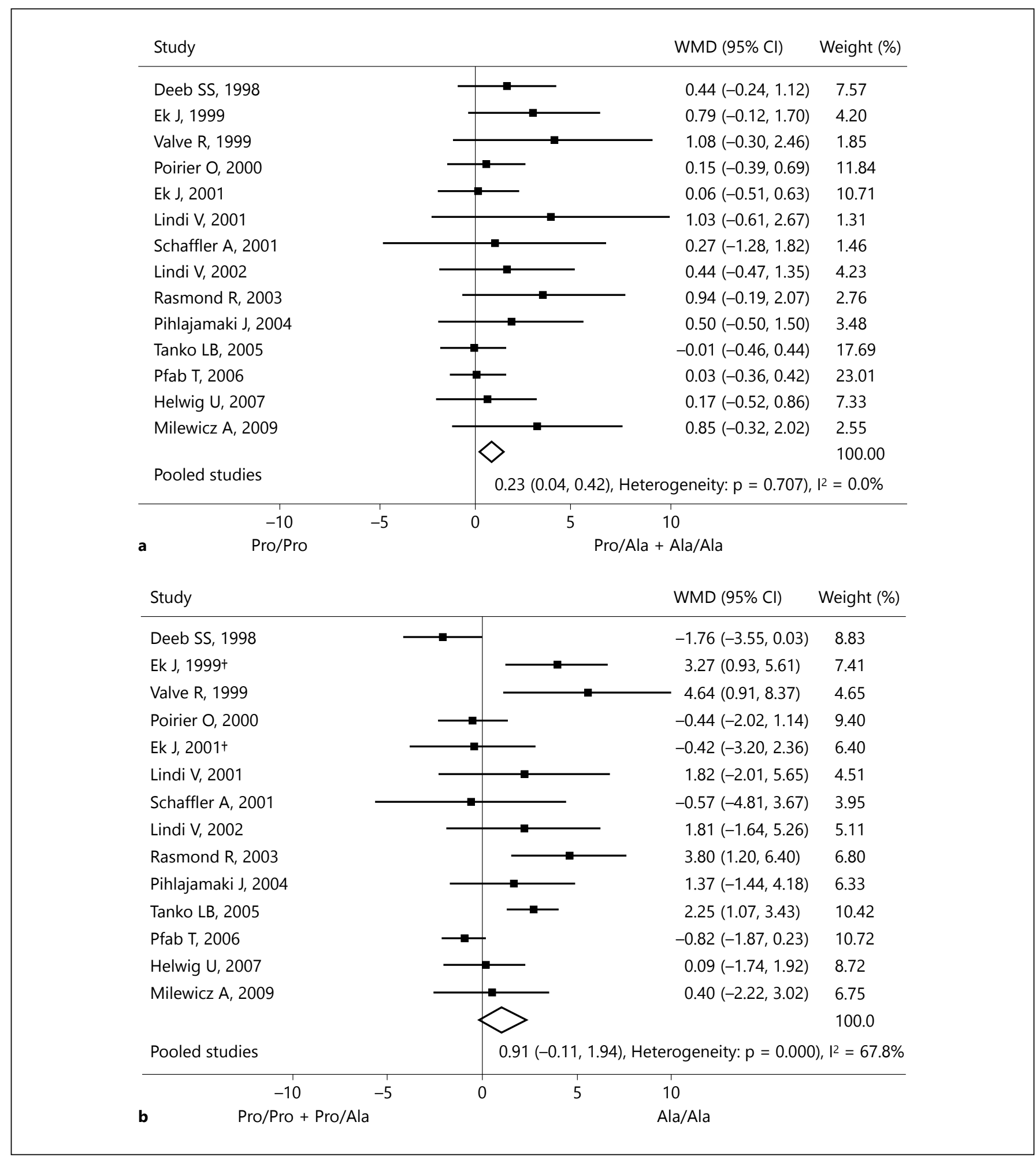

Fig. 6. a Forest plot showing individual and pooled fixed effect WMD (95\% CI) for the association between the PPAR $\gamma$ Pro12Ala polymorphisms and mean BMI under dominant inheritance model. Test of overall effect: $\mathrm{z}=2.40$, Pro/Ala + Ala/Ala vs. Pro/ Pro $\mathrm{p}=0.01$. $\mathbf{b}$ Forest plot showing individual and pooled random effect WMD (95\% CI) for the association between the PPAR $\gamma$ Pro12Ala polymorphisms and mean BMI under recessive inheritance model. Test of overall effect: $\mathrm{z}=1.74$, Ala/Ala vs. Pro/Pro + Pro/Ala $\mathrm{p}=0.08$. 


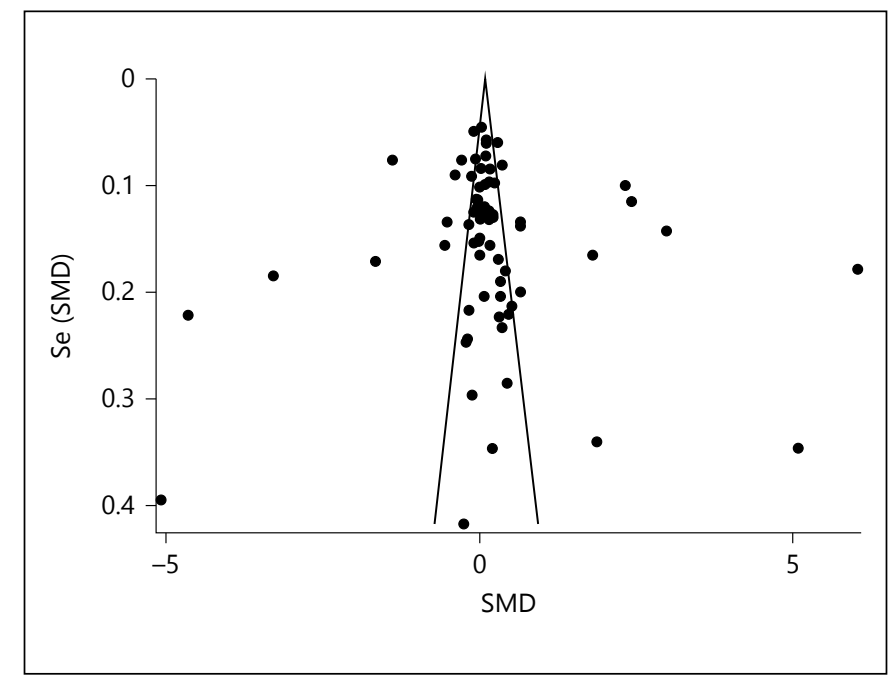

Fig. 7. Fuunel plot to assess publication bias. Circles indicate individual studies.

\section{Publication Bias}

Publication bias was examined by the visual funnel plot and the result of Egger's test. Distribution of funnel plot and the Egger's regression analysis did not show any asymmetric nature of the plot (fig. 7). Intercept $=0.15$, $95 \% \mathrm{CI}-0.07$ to $0.38, \mathrm{p}=0.19$, indicating there was no publication bias. The cumulative analyses showed the consistency of findings over time (figure not shown).

\section{Discussion}

This study suggested that the PPAR $\gamma$ Pro12Ala polymorphism was associated with the BMI level. The Ala allele of this particular SNP is associated with an increase of 0.29 units in BMI, and this association was seen in both genders. Moreover, in the meta-analysis of ethnic subgroups, the Ala allele of this particular SNP was associated with an increase of 0.18 units in BMI in Caucasians. However, this significant relationship was not observed in the Asians and mixed populations. This difference may be explained by the discrepancy in the body weight distribution and the lifestyles of the ethnic groups. Luan et al. [12] reported a gene-diet interaction with regard to PPAR $\gamma$ Pro12Ala polymorphism. They showed an inverse association between polyunsaturated to saturated fatty acids ratio with BMI and plasma insulin levels in Ala carriers [12], and in subsequent studies, the relationship between this polymorphism and nutrient intakes on BMI or waist circumference was verified $[17,18$,
27]. Thus, it might be possible that different dietary patterns between ethnic groups could modulate the relationship between BMI and this particular SNP. In the meta-analysis of BMI subgroups, Ala allele was associated with an increase of 0.96 units for BMI $\geq 35$. Moreover, when meta-analysis was restricted to Caucasians, this association was observed in individuals with $27 \leq$ $\mathrm{BMI}<35$ and $\mathrm{BMI} \geq 35$.

In most studies, because of the low frequency of Ala/ Ala genotype, BMI values were presented in the combined form of Pro/Ala and Ala/Ala. Thus, this meta-analysis was performed under a dominant model, which was a comparison between Pro/Pro genotype and combined form of Pro/Ala and Ala/Ala. Moreover, both recessive and dominant models were performed for studies that mentioned BMI values for Ala/Ala genotype. The results presented a significant relationship only in the dominant model. Therefore, the Ala allele of this particular SNP was associated with an increase in BMI under a dominant model of inheritance.

Previous studies investigated the relationship between this particular SNP and BMI, where a majority of participants were unhealthy individuals [13-15]. In a separate subgroup meta-analyses of diabetic and nondiabetic individuals, it was reported that this SNP effect on BMI was not observed in the diabetic group [14]. This confirms the necessity of excluding non-healthy individuals for exploring the real association, which was considered in these pooled analyses. Thus, in the present meta-analyses, only healthy adult participants were included. In agreement with our data, previous metaanalyses reported an association between Ala allele and $B M I$ value, especially in the $B M I \geq 27$ subgroup [13]. However, in this study, a stronger association between Ala carriers and increase in BMI value was observed (an increase of 0.06 in the previous study verses an increase of 0.29 units in the present study). The possible explanations for this discrepancy may be due to the inclusion of more studies in our meta-analyses and due to the inclusion of only healthy participants. Yao et al. [15] pooled 25 studies that showed that Ala carriers were associated with the obesity risk in comparison with the non-carriers; however, they used the odds ratio for obesity from different levels of BMI $(\geq 24, \geq 30$ and $\geq 95$ th percentile).

A plausible mechanism of the effect of this particular SNP is probably mediated by an increase in insulin sensitivity. This may be secondary to more efficient suppression of free fatty acids release from fat tissue, where PPAR $\gamma$ is expressed [76]. Stumvoll et al. [77] observed 
that during the hyper-insulinaemic clamp, non-esterified fatty acids concentration was almost $50 \%$ lower in the Ala variant. More efficient suppression of lipolysis in this group could tilt the regulated balance between lipolysis and lipogenesis slightly toward lipogenesis and weight gain.

The results of this meta-analysis should be interpreted with the consideration of some limitations. First of all, we only included the studies published in English. Second, this meta-analysis showed significant inter-studies heterogeneities, which is a common problem in meta-analysis for genetic associations [78]. However, we performed subgroups analysis and showed that the study design is a main source of heterogeneity. In most of the subgroup analyses, heterogeneity remained, and this suggests that heterogeneity in our study could be due to other factors. Third, other SNPs and environmental factors involved in $\mathrm{BMI}$ value were not considered confounders because of lack of sufficient data. The major strengths are the large sample size and the absence of publication bias. We also conducted extensive sensitivity analyses excluding studies that did not meet specific criteria for study design.

In conclusion, our results suggest that the Ala allele of the PPAR $\gamma$ Pro12Ala polymorphism is associated with increased BMI under a dominant model of inheritance in both genders. In subgroup analyses, this relationship was seen only in the higher levels of BMI (BMI $\geq 35$ ) and among Caucasians. Further studies considering gene-gene and gene-environment interaction are potentially recommended to elucidate these associations more clearly.

\section{Disclosure Statement}

None of the authors had any personal or financial conflicts of interest.

\section{References}

1 Kelishadi R: Childhood overweight, obesity, and the metabolic syndrome in developing countries. Epidemiol Rev 2007;29:62-76.

2 Rankinen T, Zuberi A, Chagnon YC, Weisnagel SJ, Argyropoulos G, Walts B, Pérusse L, Bouchard C: The human obesity gene map: the 2005 update. Obesity 2006;14:529-644.

-3 Auwerx J: PPARgamma, the ultimate thrifty gene. Diabetologia 1999;42:1033-1049.

-4 Yen CJ, Beamer BA, Negri C, Silver K, Brown KA, Yarnall DP, Burns DK, Roth J, Shuldiner AR: Molecular scanning of the human peroxisome proliferator activated receptor gamma (hPPAR gamma) gene in diabetic Caucasians: identification of a Pro12Ala PPAR gamma 2 missense mutation. Biochem Biophys Res Commun 1997;241:270-274.

5 Deeb SS, Fajas L, Nemoto M, Pihlajamäki J, Mykkänen L, Kuusisto J, Laakso M, Fujimoto W, Auwerx J: A Pro12Ala substitution in PPARgamma2 associated with decreased receptor activity, lower body mass index and improved insulin sensitivity. Nat Genet 1998; 20:284-287.

6 Sladek R, Rocheleau G, Rung J, Dina C, Shen L, Serre D, Boutin P, Vincent D, Belisle A, Hadjadj S: A genome-wide association study identifies novel risk loci for type 2 diabetes. Nature 2007;445:881-885.

7 Canizales-Quinteros S, Aguilar-Salinas CA, Ortiz-López MG, Rodríguez-Cruz M, Villarreal-Molina MT, Coral-Vázquez R, HuertasVázquez A, Hernández-Caballero A, LópezAlarcón M, Brito-Zurita OR, et al: Association of PPARG2 Pro12Ala variant with larger body mass index in Mestizo and Amerindian populations of Mexico. Hum Biol 2007;79: 111-119.
-8 Franks PW, Jablonski KA, Delahanty L, Hanson RL, Kahn SE, Altshuler D, Knowler WC, Florez JC: The Pro12Ala variant at the peroxisome proliferator-activated receptor gamma gene and change in obesity-related traits in the diabetes prevention program. Diabetologia 2007;50:2451-2460.

$\checkmark 9$ Cole SA, Mitchell BD, Hsueh WC, Pineda P, Beamer BA, Shuldiner AR, Comuzzie AG, Blangero J, Hixson JE: The Pro12Ala variant of peroxisome proliferator-activated receptor-gamma2 (PPAR-gamma2) is associated with measures of obesity in Mexican Americans. Int J Obes Relat Metab Disord 2000;24:522-524.

10 Beamer BA, Yen CJ, Andersen RE, Muller D, Elahi D, Cheskin LJ, Andres R, Roth J, Shuldiner AR: Association of the Pro12Ala variant in the peroxisome proliferator-activated receptor-gamma2 gene with obesity in two Caucasian populations. Diabetes 1998;47: 1806-1808.

11 Siitonen N, Lindström J, Eriksson J, Valle TT, Hämäläinen $\mathrm{H}$, Ilanne-Parikka $\mathrm{P}$, KeinänenKiukaanniemi S, Tuomilehto J, Laakso M, Uusitupa M: Association between a deletion/ insertion polymorphism in the alpha2B-adrenergic receptor gene and insulin secretion and type 2 diabetes. The Finnish diabetes prevention study. Diabetologia 2004;47:14161424.

12 Luan J, Browne PO, Harding AH, Halsall DJ, O'Rahilly S, Chatterjee VK, Wareham NJ: Evidence for gene-nutrient interaction at the PPARgamma locus. Diabetes 2001;50:686689.

13 Masud S, Ye S: Effect of the peroxisome proliferator activated receptor-gamma gene
Pro12Ala variant on body mass index: a meta-analysis. J Med Genet 2003;40:773780.

14 Galbete C, Toledo E, Martínez-González MA Martínez JA, Guillén-Grima F, Marti A: Pro12Ala variant of the PPARG2 gene increases body mass index: an updated metaanalysis encompassing 49,092 subjects. Obesity (Silver Spring) 2013;21:1486-1495.

15 Yao YS, Li J, Jin YL, Chen Y, He LP: Association between PPAR- $\gamma 2$ Pro12Ala polymorphism and obesity: a meta-analysis. Mol Biol Rep 2015;42:1029-1038.

16 Poljicanin T, Pavlić-Renar I, Metelko Z: Obesity in type 2 diabetes: prevalence, treatment trends and dilemmas. Coll Antropol 2011;35: 829-834.

17 Vaccaro O, Lapice E, Monticelli A, Giacchetti M, Castaldo I, Galasso R, Pinelli M, Donnarumma $G$, Rivellese AA, Cocozza $S$, et al: Pro12Ala polymorphism of the PPARgamma2 locus modulates the relationship between energy intake and body weight in type 2 diabetic patients. Diabetes Care 2007;30:11561161.

18 Memisoglu A, Hu FB, Hankinson SE, Manson JE, De Vivo I, Willett WC, Hunter DJ: Interaction between a peroxisome proliferator-activated receptor gamma gene polymorphism and dietary fat intake in relation to body mass. Hum Mol Genet 2003;12:2923-2929.

19 Moher D, Liberati A, Tetzlaff J, Altman DG: Preferred reporting items for systematic reviews and meta-analyses: the PRISMA statement. Ann Intern Med 2009;151:264-269.

20 Lau J, Ioannidis JP, Schmid CH: Quantitative synthesis in systematic reviews. Ann Intern Med 1997;127:820-826. 
21 Higgins JP, Thompson SG: Quantifying heterogeneity in a meta-analysis. Stat Med 2002; 21:1539-1558.

-22 Van Houwelingen HC, Arends LR, Stijnen T: Advanced methods in meta-analysis: multivariate approach and meta-regression. Stat Med 2002;21:589-624.

-23 Lau J, Antman EM, Jimenez-Silva J, Kupelnick B, Mosteller F, Chalmers TC: Cumulative meta-analysis of therapeutic trials for myocardial infarction. N Engl J Med 1992; 327:248-254.

24 Egger M, Davey Smith G, Schneider M, Minder C: Bias in meta-analysis detected by a simple, graphical test. BMJ 1997;315:629-634.

-25 Lindi V, Sivenius K, Niskanen L, Laakso M, Uusitupa MI: Effect of the Pro12Ala polymorphism of the PPAR-gamma2 gene on longterm weight change in Finnish non-diabetic subjects. Diabetologia 2001;44:925-926.

-26 Schäffler A, Barth N, Schmitz G, Zietz B, Palitzsch KD, Schölmerich J: Frequency and significance of Pro12Ala and Pro115Gln polymorphism in gene for peroxisome proliferation-activated receptor-gamma regarding metabolic parameters in a Caucasian cohort. Endocrine 2001;14:369-373.

-27 Robitaille J, Després JP, Pérusse L, Vohl MC The PPAR-gamma P12A polymorphism modulates the relationship between dietary fat intake and components of the metabolic syndrome: results from the Québec family study. Clin Genet 2003;63:109-116.

28 Pihlajamäki J, Vanhala M, Vanhala P, Laakso M: The Pro12Ala polymorphism of the PPAR gamma 2 gene regulates weight from birth to adulthood. Obes Res 2004;12:187-190.

-29 Franks PW, Luan J, Browne PO, Harding AH, O'Rahilly S, Chatterjee VK, Wareham NJ: Does peroxisome proliferator-activated receptor gamma genotype (Pro12ala) modify the association of physical activity and dietary fat with fasting insulin level? Metabolism 2004;53:11-16.

-30 Yaffe K, Kanaya AM, Lindquist K, Hsueh WC, Cummings SR, Beamer B, Newman A, Rosano C, Li R, Harris T: PPAR-gamma Pro12Ala genotype and risk of cognitive decline in elders. Neurobiol Aging 2008;29:78-83.

- 31 Haseeb A, Iliyas M, Chakrabarti S, Farooqui AA, Naik SR, Ghosh S, Suragani M, Ehtesham NZ: Single-nucleotide polymorphisms in peroxisome proliferator-activated receptor gam$\mathrm{ma}$ and their association with plasma levels of resistin and the metabolic syndrome in a South Indian population. J Biosci 2009;34: 405-414.

- 32 Aldhoon B, Zamrazilová H, Aldhoon Hainerová I, Srámková P, Spálová J, Kunesová $\mathrm{M}$, Bendlová B, Hainer V: Role of the PPARalpha Leu162Val and PPARgamma2 Pro12Ala gene polymorphisms in weight change after 2.5-year follow-up in Czech obese women. Folia Biol (Praha) 2010;56:116-123.

- 33 Ek J, Urhammer SA, Sørensen TI, Andersen T, Auwerx J, Pedersen O: Homozygosity of the Pro12Ala variant of the peroxisome proliferation-activated receptor-gamma2 (PPAR-gamma2): divergent modulating effects on body mass index in obese and lean Caucasian men. Diabetologia 1999;42:892895.

34 Clement K, Hercberg S, Passinge B, Galan P, Varroud-Vial M, Shuldiner AR, Beamer BA, Charpentier G, Guy-Grand B, Froguel P, et al: The Pro115Gln and Pro12Ala PPAR gamma gene mutations in obesity and type 2 diabetes. Int J Obes Relat Metab Disord 2000;24:391393.

35 Ek J, Andersen G, Urhammer SA, Hansen L, Carstensen B, Borch-Johnsen K, Drivsholm T, Berglund L, Hansen T, Lithell H, et al: Studies of the Pro12Ala polymorphism of the peroxisome proliferator-activated receptorgamma2 (PPAR-gamma2) gene in relation to insulin sensitivity among glucose tolerant caucasians. Diabetologia 2001;44:1170-1176.

36 Swarbrick MM, Chapman CM, McQuillan BM, Hung J, Thompson PL, Beilby JP: A Pro12Ala polymorphism in the human peroxisome proliferator-activated receptor-gamma 2 is associated with combined hyperlipidaemia in obesity. Eur J Endocrinol 2001;144: 277-282.

37 González Sánchez JL, Serrano Ríos M, Fernández Perez C, Laakso M, Martínez Larrad MT: Effect of the Pro12Ala polymorphism of the peroxisome proliferator-activated receptor gamma-2 gene on adiposity, insulin sensitivity and lipid profile in the Spanish population. Eur J Endocrinol 2002;147:495501.

38 Ghoussaini M, Meyre D, Lobbens S, Charpentier G, Clément K, Charles MA, Tauber M, Weill J, Froguel P: Implication of the Pro12Ala polymorphism of the PPAR-gamma 2 gene in type 2 diabetes and obesity in the French population. BMC Med Genet 2005;6:11.

39 Mirzaei H, Akrami SM, Golmohammadi T, Doosti M, Heshmat R, Nakhjavani M, Amiri P: Polymorphism of Pro12Ala in the peroxisome proliferator-activated receptor gamma2 gene in Iranian diabetic and obese subjects. Metab Syndr Relat Disord 2009;7:453-458.

40 Mori Y, Kim-Motoyama H, Katakura T, Yasuda K, Kadowaki H, Beamer BA, Shuldiner AR, Akanuma Y, Yazaki Y, Kadowaki T: Effect of the Pro12Ala variant of the human peroxisome proliferator-activated receptor gamma 2 gene on adiposity, fat distribution, and insulin sensitivity in Japanese men. Biochem Biophys Res Commun 1998;251:195-198.

41 Valve R, Sivenius K, Miettinen R, Pihlajamäki J, Rissanen A, Deeb SS, Auwerx J, Uusitupa M, Laakso M: Two polymorphisms in the peroxisome proliferator-activated receptorgamma gene are associated with severe overweight among obese women. J Clin Endocrinol Metab 1999;84:3708-3712.

42 Meirhaeghe A, Fajas L, Helbecque N, Cottel D, Auwerx J, Deeb SS, Amouyel P: Impact of the peroxisome proliferator activated receptor gamma2 Pro12Ala polymorphism on adiposity, lipids and non-insulin-dependent dia- betes mellitus. Int J Obes Relat Metab Disord 2000;24:195-199.

43 Poirier O, Nicaud V, Cambien F, Tiret L: The Pro12Ala polymorphism in the peroxisome proliferator-activated receptor gamma2 gene is not associated with postprandial responses to glucose or fat tolerance tests in young healthy subjects: the European atherosclerosis research study II. J Mol Med (Berl) 2000; 78:346-351.

44 Vaccaro O, Mancini FP, Ruffa G, Sabatino L, Iovine C, Masulli M, Colantuoni V, Riccardi G: Fasting plasma free fatty acid concentrations and Pro12Ala polymorphism of the peroxisome proliferator-activated receptor (PPAR) gamma2 gene in healthy individuals. Clin Endocrinol (Oxf) 2002;57:481-486.

45 Eriksson JG, Lindi V, Uusitupa M, Forsén TJ, Laakso M, Osmond C, Barker DJ: The effects of the Pro12Ala polymorphism of the peroxisome proliferator-activated receptor-gamma2 gene on insulin sensitivity and insulin metabolism interact with size at birth. Diabetes 2002;51:2321-2324.

-46 Baratta R, Di Paola R, Spampinato D, Fini G, Marucci A, Coco A, Vigneri R, Frittitta L, Trischitta V: Evidence for genetic epistasis in human insulin resistance: the combined effect of PC-1 (K121Q) and PPARgamma2 (P12A) polymorphisms. J Mol Med (Berl) 2003;81: 718-723.

47 Rosmond R, Chagnon M, Bouchard C: The Pro12Ala PPARgamma2 gene missense mutation is associated with obesity and insulin resistance in Swedish middle-aged men. Diabetes Metab Res Rev 2003;19:159-163.

48 Buzzetti R, Petrone A, Ribaudo MC, Alemanno I, Zavarella S, Mein CA, Maiani F, Tiberti C, Baroni MG, Vecci E, et al: The common PPAR-gamma2 Pro12Ala variant is associated with greater insulin sensitivity. Eur J Hum Genet 2004;12:1050-1054

49 Tai ES, Corella D, Deurenberg-Yap M, Adiconis X, Chew SK, Tan CE, Ordovas JM: Differential effects of the C1431T and Pro12Ala PPARgamma gene variants on plasma lipids and diabetes risk in an Asian population. J Lipid Res 2004;45:674-685.

50 Takata N, Awata T, Inukai K, Watanabe M, Ohkubo T, Kurihara S, Inaba M, Katayama S: Pro12Ala substitution in peroxisome proliferator-activated receptor gamma 2 is associated with low adiponectin concentrations in young Japanese men. Metabolism 2004;53: 1548-1551.

51 Barbieri M, Rizzo MR, Papa M, Acampora R, De Angelis L, Olivieri F, Marchegiani F, Franceschi C, Paolisso G: Role of interaction between variants in the PPARG and interleukin- 6 genes on obesity related metabolic risk factors. Exp Gerontol 2005;40:599-604.

52 Meirhaeghe A, Tanck MW, Fajas L, Janot C, Helbecque N, Cottel D, Auwerx J, Amouyel P, Dallongeville J: Study of a new PPARgamma2 promoter polymorphism and haplotype analysis in a French population. Mol Genet Metab 2005;85:140-148.
PPAR $\gamma$ Pro12Ala Polymorphism in Relation to Obesity 
53 Tankó LB, Siddiq A, Lecoeur C, Larsen PJ, Christiansen C, Walley A, Froguel P: ACDC/ adiponectin and PPAR-gamma gene polymorphisms: implications for features of obesity. Obes Res 2005;13:2113-2121.

54 Pfab T, Poralla C, Richter CM, Godes M, Slowinski T, Priem F, Halle H, Hocher B: Fetal and maternal peroxisome proliferator-activated receptor gamma2 Pro12Ala does not influence birth weight. Obesity (Silver Spring) 2006;14:1880-1885.

55 Rhee EJ, Oh KW, Lee WY, Kim SY, Oh ES, Baek KH, Kang MI, Kim SW: Effects of two common polymorphisms of peroxisome proliferator-activated receptor-gamma gene on metabolic syndrome. Arch Med Res 2006;37: 86-94.

56 Hamada T, Kotani K, Tsuzaki K, Sano Y, Murata T, Tabata M, Sato S, Sakane N: Association of Pro12Ala polymorphism in the peroxisome proliferator-activated receptor gamma2 gene with small dense low-density lipoprotein in the general population. Metabolism 2007; 56:1345-1349.

57 Helwig U, Rubin D, Kiosz J, Schreiber S, Fölsch UR, Nothnagel M, Döring F, Schrezenmeir J: The minor allele of the PPARgamma2 pro12Ala polymorphism is associated with lower postprandial TAG and insulin levels in non-obese healthy men. Br J Nutr 2007;97: 847-854.

58 Meshkani R, Taghikhani M, Larijani B, Bahrami Y, Khatami S, Khoshbin E, Ghaemi A, Sadeghi S, Mirkhani F, Molapour A, et al: Pro12Ala polymorphism of the peroxisome proliferator-activated receptor-gamma2 (PPARgamma-2) gene is associated with greater insulin sensitivity and decreased risk of type 2 diabetes in an Iranian population. Clin Chem Lab Med 2007;45:477-482.

59 Kim K, Lee S, Valentine RJ: Association of pro12Ala polymorphism in the peroxisome proliferative-activated receptor gamma2 gene with obesity and hypertension in Korean women. J Nutr Sci Vitaminol (Tokyo) 2007; 53:239-246.

60 Mattevi VS, Zembrzuski VM, Hutz MH: Effects of a PPARG gene variant on obesity characteristics in Brazil. Braz J Med Biol Res 2007;40:927-932.

61 Morini E, Tassi V, Capponi D, Ludovico O, Dallapiccola B, Trischitta V, Prudente S: Interaction between PPARgamma2 variants and gender on the modulation of body weight. Obesity (Silver Spring) 2008;16: 1467-1470

62 Bendlová B, Vejrazková D, Vcelák J, Lukásová $\mathrm{P}$, Burkonová D, Kunesová M, Vrbíková J, Dvoráková K, Vondra K, Vanková M: PPARgamma2 Pro12Ala polymorphism in relation to free fatty acids concentration and composition in lean healthy Czech individuals with and without family history of diabetes type 2 . Physiol Res 2008;57(suppl 1):S77-S90.

63 Ruchat SM, Weisnagel SJ, Vohl MC, Rankinen T, Bouchard C, Pérusse L: Evidence for interaction between PPARG Pro12Ala and PPARGC1A Gly482Ser polymorphisms in determining type 2 diabetes intermediate phenotypes in overweight subjects. Exp Clin Endocrinol Diabetes 2009;117:455-459.

64 Milewicz A, Tworowska-Bardziñska U, Dunajska K, Jêdrzejuk D, Lwow F: Relationship of PPARgamma2 polymorphism with obesity and metabolic syndrome in postmenopausal Polish women. Exp Clin Endocrinol Diabetes 2009; 117:628-632.

65 Ben Ali S, Ben Yahia F, Sediri Y, Kallel A, Ftouhi B, Feki M, Elasmi M, Haj-Taieb S, Souheil O, Sanhagi H, et al: Gender-specific effect of Pro12Ala polymorphism in peroxisome proliferator-activated receptor gamma-2 gene on obesity risk and leptin levels in a Tunisian population. Clin Biochem 2009; 42:1642-1647.

66 Passaro A, Dalla Nora E, Marcello C, Di Vece F, Morieri ML, Sanz JM, Bosi C, Fellin R, Zuliani G: PPARy Pro12Ala and ACE ID polymorphisms are associated with BMI and fat distribution, but not metabolic syndrome. Cardiovasc Diabetol 2011;10:112.

67 Stumvoll M, Stefan N, Fritsche A, Madaus A, Tschritter O, Koch M, Machicao F, Häring H: Interaction effect between common polymorphisms in PPARgamma2 (Pro12Ala) and insulin receptor substrate 1 (Gly972Arg) on insulin sensitivity. J Mol Med (Berl) 2002;80: 33-38.

68 Nicklas BJ, van Rossum EF, Berman DM, Ryan AS, Dennis KE, Shuldiner AR: Genetic variation in the peroxisome proliferator-activated receptor-gamma2 gene (Pro12Ala) affects metabolic responses to weight loss and subsequent weight regain. Diabetes 2001;50: 2172-2176

69 Thamer C, Haap M, Volk A, Maerker E, Becker R, Bachmann O, Machicao F, Häring HU, Stumvoll M: Evidence for greater oxidative substrate flexibility in male carriers of the Pro 12 Ala polymorphism in PPARgamma2. Horm Metab Res 2002;34:132-136.

70 Lindi VI, Uusitupa MI, Lindström J, Louheranta A, Eriksson JG, Valle TT, Hämäläinen H, Ilanne-Parikka P, Keinänen-Kiukaanniemi S, Laakso M, et al: Association of the Pro12Ala polymorphism in the PPAR-gamma2 gene with 3-year incidence of type 2 diabetes and body weight change in the Finnish diabetes prevention study. Diabetes 2002;51:25812586.

71 Kahara T, Takamura T, Hayakawa T, Nagai Y, Yamaguchi H, Katsuki T, Katsuki K, Katsuki M, Kobayashi K: PPARgamma gene polymorphism is associated with exercise-mediated changes of insulin resistance in healthy men. Metabolism 2003;52:209-212.

72 Kim KS, Choi SM, Shin SU, Yang HS, Yoon Y: Effects of peroxisome proliferator-activated receptor-gamma2 Pro12Ala polymorphism on body fat distribution in female Korean subjects. Metabolism 2004;53:1538-1543.

73 Ramírez-Salazar M, Pérez-Luque E, FajardoAraujo M, Garza SM, Malacara JM: Effect of the Pro12Ala polymorphism of the PPAR gamma 2 gene on response to pioglitazone treatment in menopausal women. Menopause 2008;15:1151-1156.

74 Rosado EL, Bressan J, Martínez JA, MarquesLopes I: Interactions of the PPAR $\gamma 2$ polymorphism with fat intake affecting energy metabolism and nutritional outcomes in obese women. Ann Nutr Metab 2010;57:242-250.

75 Garaulet M, Smith CE, Hernández-González T, Lee YC, Ordovás JM: PPAR $\gamma$ Pro12Ala interacts with fat intake for obesity and weight loss in a behavioural treatment based on the Mediterranean diet. Mol Nutr Food Res 2011; 55:1771-1779.

76 Stumvoll M, Wahl HG, Löblein K, Becker R, Machicao F, Jacob S, Häring H: Pro12Ala polymorphism in the peroxisome proliferator - activated receptor-gamma2 gene is associated with increased antilipolytic insulin sensitivity. Diabetes 2001;50:876-881.

77 Stumvoll M, Häring H: Reduced lipolysis as possible cause for greater weight gain in subjects with the Pro12Ala polymorphism in PPARgamma2? Diabetologia 2002;45:152153.

78 Munafò MR, Flint J: Meta-analysis of genetic association studies. Trends Genet 2004;20: 439-444. 